\title{
Association between clinical manifestations of sickle cell anemia in children and the occurrence of dental caries: a cross-sectional study
}

Associação entre manifestações clínicas da anemia falciforme em crianças e a ocorrência de cárie dentária: um estudo de corte transversal

Anderson Santos CARVALHO ${ }^{1,2}$, Danilo Antônio da Silva DUARTE ${ }^{2}$, José Leopoldo Ferreira ANTUNES ${ }^{3}$, Maria Isabel Pereira VIANNA ${ }^{1}$ and Maria Cristina Teixeira CANGUSSU ${ }^{1}$

1 - Dentistry and Health Postgraduate Program - School of Dentistry - Federal University of Bahia - Salvador - BA - Brazil.

2 - Postgraduate Program in Dental Sciences (paediatric dentistry) - School of Dentistry - São Leopoldo Mandic - Campinas - SP - Brazil.

3 - School of Public Health - University of São Paulo - São Paulo - SP - Brazil.

\section{ABSTRACT}

Objective: The aim of this study was to determine the association between clinical manifestations of sickle cell anemia (including hospitalization and pain crisis) and dental caries in children in Bahia. Material and Methods: The study design was crosssectional, and the population included children aged from 6 to 96 months from August 2007 to July 2008 $(\mathrm{N}=686)$. Interviews were performed to identify the sociodemographic profiles of the participants, and oral examinations were conducted by three examiners who were previously trained and calibrated to identify the presence of dental caries according to World Health Organization (WHO) criteria. Logistic regression analysis was performed for confirmatory analysis and estimation of confidence intervals (CIs). Results: The results showed that pain crises and hospitalizations were positively associated with caries (crude odds ratio $(\mathrm{OR})=2.11$ and adjusted $\mathrm{OR}=1.24$; crude $\mathrm{OR}=2.50$ and adjusted $\mathrm{OR}=$ 1.46 , respectively), but these associations were not statistically significant. Conclusion: The severity of the sickle cell condition alone was not sufficient to aggravate the prevalence of caries; thus, there are no major differences in caries prevalence between children with and without sickle cell disease.

\section{KEYWORDS}

Sickle cell anemia; Dental caries; Epidemiology; Paediatrics.

\section{RESUMO}

Objetivo: O objetivo deste estudo foi determinar a associação entre as manifestações clínicas da anemia falciforme (incluindo hospitalização e crise de dor) e cárie dentária em crianças na Bahia. Material e Métodos: O desenho do estudo foi transversal e a população incluiu crianças de 6 a 96 meses de agosto de 2007 a julho de $2008(\mathrm{~N}=686)$. Foram realizadas entrevistas para identificar os perfis sociodemográficos dos participantes, e os exames bucais foram realizados por três examinadores previamente treinados e calibrados para identificar a presença de cárie dentária de acordo com os critérios da Organização Mundial da Saúde (OMS). A análise de regressão logística foi realizada para análise confirmatória e estimativa de intervalos de confiança (IC). Resultados: Os resultados mostraram que as crises de dor e hospitalizações foram positivamente associadas à cárie (razão de chances bruta $(\mathrm{OR})=2,11$ e OR ajustado $=1,24$; OR bruto $=2,50$ e OR ajustado $=1,46$, respectivamente), mas essas associações não foram estatisticamente significantes. Conclusão: A gravidade da doença falciforme isoladamente não foi suficiente para agravar a prevalência de cárie; assim, não há grandes diferenças na prevalência de cárie entre crianças com e sem doença falciforme.

\section{PALAVRAS-CHAVE}

Anemia falciforme; Cárie dentária; Epidemiologia; Odontopediatria. 


\section{INTRODUCTION}

\begin{abstract}
s sickle-cell anemia is a disease that can cause systemic impairment, resulting in complications that usually require additional care such as hospitalizations and constant use of medications, it is necessary to pay greater attention to individuals with this condition because they are in a position of physical and social vulnerability [1]. Often, concern with the suffering caused by clinical symptoms results in an inattention to oral care, which can lead to a greater risk and susceptibility to dental caries, but there is no consensus with regard to the findings on this subject.
\end{abstract}

Among the studies performed to establish a relationship between caries disease and sickle-cell anemia, Passos et al. [2] reported the findings of a case-control study using the CPO-D index of adult individuals with and without the disease. The results showed that factors already known to cause caries had a greater influence than those directly related to the severity of sickle cell anemia evaluated by the frequency of the vasoconstrictive crisis, the presence of leg ulcers, jaundice, stroke and femoral necrosis. Fernandes et al. [3] carried out a study comparing the ceo-d/CPO-D index of children and adolescents with sickle cell anemia with a control group without the disease, and it was observed that in the younger age group (8 to 10 years), the values of ceo-d/ CPO-D were significantly lower than those of the group of healthy children. In addition, the severity of sickle cell disease, as assessed by the number of episodes of pain crises, number and duration of hospitalizations, comorbidities, presence of ulcers and transfusions, influenced the increased dental caries in children with sickle cell anemia, unlike socioeconomic characteristics.

Due to these conflicting findings, it is important to study the influence of factors related to the severity of the manifestations of the disease, including the occurrence of hospitalizations, manifestations of pain crises, and the occurrence of dental alteration, as there is no consensus on the true relationship between these factors. Furthermore, the concern regarding suffering related to clinical symptoms causes a lack of attention to oral care, leading to a greater risk of and susceptibility to dental caries.

In light of the above, the objective of the present study is to evaluate the relationship between the severity of sickle cell anemia through the clinical manifestations of the disease and the occurrence of caries in order to clarify a possible association between them.

\section{MATERIAL AND METHODS}

This was a cross-sectional study in which the study population consisted of children who were regularly attended by the Haematology Service of the Neonatal Screening Sector of the APAE-the Association of Parents and Friends of the Exceptional in Salvador-BA, the only service accredited by the Ministry of Health and the Health Secretary of the State of Bahia (SESAB)—from August 2007 to July 2008. The data for these children were obtained from a census form $(n=704)$.

For the present study, inclusion criteria were as follows: a minimum age of 6 months, diagnostic confirmation of sickle cell disease, and consent by parents or guardians for participation through signing the consent form.

The information was obtained from a primary source: a questionnaire given to the families of the child with the disease. Data were collected on the sociodemographic condition of the family, the child's health condition, the child's behavioural condition and serious child health events. A clinical examination using a wooden spatula and natural light was conducted to evaluate the condition of dental caries in the children according to the 1997 World Health Organization (WHO) criteria. A total of 3 teams participated in the collection, including examiners and scorers, who had been previously trained and calibrated for all evaluated conditions. The inter-examiner and intra-examiner agreement was verified through general agreement and the kappa test (0.79 and 0.82 , respectively). 
The variables analysed were as follows. The independent variables included the prevalence of severe clinical manifestations in the child, as shown by pain episodes in the last 6 months (0 - no, 1 - yes) and hospitalizations in the last 6 months (0 - no, 1 - yes). The dependent variable was the caries condition of the child, represented by the prevalence of the disease ( 0 - caries free, 1 - presence of at least 1 tooth affected by the disease).

The following covariates were dichotomized and analysed: demographic variables (child's age (0 - 6 to 36 months, 1 - older than 36 months), sex (0 - male, 1 female), skin colour (0 - other, 1 - black)), socioeconomic variables (mother's level of education ( 0 - incomplete high school or more, 1 - until elementary school), family income (0 - 1 minimum salary or more, $1-<1$ minimum salary), number of siblings ( 0 - 1 sibling, $1 \geq$ 2 siblings), number of people in the household (0 - < 4 people, $1-\geq 5$ people), number of rooms ( $0-\geq 6$ rooms, $1-<5$ rooms $)$ ), buccal factors (dental appointment (0 - yes or 1- no), diet with sugar (0 - no or 1 - yes)).

Statistical analysis was performed using Minitab ${ }^{\circledR}$ (USA) version 14.0. Descriptive analyses were conducted to obtain the measures of central tendency, variability in continuous variables, and absolute and relative frequencies of the categories. The main association related to the outcome variable (dental caries occurrence) was analysed, followed by stratified analyses using the chi-square test $(x 2)$, adopting a significance level of $5 \%$, for a preliminary assessment of potential confounding variables insofar as crude associations between the variables of interest were estimated. Multivariate logistic regression was used in confirmatory analysis, and these variables were inserted into the model to reach the final model through regression.

The project was submitted to the Ethics Committee of the HUPES Complex and was approved under protocol number 03/2008.

\section{RESULTS}

The sample consisted of 686 children, with 18 (approximately 2.5\%) lost due to the lack of age recording. The age range of the included children varied from 6 to 96 months (mean age 37.8 months). The sociodemographic data are shown in Table I.

Regarding the clinical condition associated with sickle cell anemia, $46.65 \%$ of the children analysed had pain attacks, and $34.69 \%$ had episodes of hospitalization.

The studied population presented a mean dmf-t of 0.89 (SD $= \pm 2.22$ ) and a caries prevalence of $21.72 \%$. When analysed by age group, the dmf-t was 0.31 (SD $= \pm$ 1.35) in the group of children aged from 6 to 36 months, and the prevalence of caries was 9.09\%; in the group of children aged from 37 to 96 months, these values increased to 1.86 $(S D=2.94)$ and $42.80 \%$, respectively.

Table I - Absolute and relative frequencies of the characterization of the sample of 6- to 96-month-old children with sickle cell anemia in the state of Bahia

\begin{tabular}{|c|c|c|c|}
\hline \multicolumn{2}{|l|}{ Demographic conditions } & \multirow{2}{*}{$\begin{array}{c}\mathbf{N} \\
346 \\
340\end{array}$} & \multirow{2}{*}{$\begin{array}{c}\% \\
50.44 \\
49.56\end{array}$} \\
\hline Sex & $\begin{array}{l}\text { Male } \\
\text { Female }\end{array}$ & & \\
\hline Age & $\begin{array}{l}6 \text { to } 36 \text { months } \\
37 \text { to } 96 \text { months }\end{array}$ & $\begin{array}{l}429 \\
257\end{array}$ & $\begin{array}{l}62.54 \\
37.46\end{array}$ \\
\hline Skin colour & $\begin{array}{l}\text { Black } \\
\text { Others }\end{array}$ & $\begin{array}{l}553 \\
133\end{array}$ & $\begin{array}{l}80.61 \\
19.39\end{array}$ \\
\hline Socioeconomic conditions & & $\mathbf{N}$ & $\%$ \\
\hline Mother's level of education & $\begin{array}{l}\text { Until elementary school } \\
\text { Incomplete high school or more }\end{array}$ & $\begin{array}{l}401 \\
285\end{array}$ & $\begin{array}{l}58.45 \\
41.55\end{array}$ \\
\hline Family income & $\begin{array}{l}<1 \text { minimum salary } \\
\geq 1 \text { minimum salary }\end{array}$ & $\begin{array}{l}507 \\
179\end{array}$ & $\begin{array}{l}73.91 \\
26.09\end{array}$ \\
\hline Number of siblings & $\begin{array}{c}1 \\
\geq 2\end{array}$ & $\begin{array}{l}443 \\
243\end{array}$ & $\begin{array}{l}64.58 \\
35.42\end{array}$ \\
\hline $\begin{array}{l}\text { Number of people in the } \\
\text { household }\end{array}$ & $\begin{array}{l}\leq 4 \\
\geq 5\end{array}$ & $\begin{array}{l}426 \\
260\end{array}$ & $\begin{array}{l}62.10 \\
37.90\end{array}$ \\
\hline Number of rooms & $\begin{array}{l}\leq 5 \\
\geq 6\end{array}$ & $\begin{array}{l}441 \\
245\end{array}$ & $\begin{array}{l}72.01 \\
27.99\end{array}$ \\
\hline Buccal factors & & $\mathbf{N}$ & $\%$ \\
\hline Sugar consumption & $\begin{array}{l}\text { Yes } \\
\text { No }\end{array}$ & $\begin{array}{l}396 \\
290\end{array}$ & $\begin{array}{l}57.79 \\
42.27\end{array}$ \\
\hline Dental appointment & $\begin{array}{l}\text { Yes } \\
\text { No }\end{array}$ & $\begin{array}{l}323 \\
363\end{array}$ & $\begin{array}{l}47.08 \\
52.92\end{array}$ \\
\hline Number of siblings & $\begin{array}{c}1 \\
\geq 2\end{array}$ & $\begin{array}{l}443 \\
243\end{array}$ & $\begin{array}{l}64.58 \\
35.42\end{array}$ \\
\hline $\begin{array}{l}\text { Number of people in the } \\
\text { household }\end{array}$ & $\begin{array}{l}\leq 4 \\
\geq 5\end{array}$ & $\begin{array}{l}426 \\
260\end{array}$ & $\begin{array}{l}62.10 \\
37.90\end{array}$ \\
\hline Number of rooms & $\begin{array}{l}\leq 5 \\
\geq 6\end{array}$ & $\begin{array}{l}441 \\
245\end{array}$ & $\begin{array}{l}72.01 \\
27.99\end{array}$ \\
\hline Clinical conditions related $t$ & sickle cell anemia & N & $\%$ \\
\hline Pain crisis & $\begin{array}{l}\text { Yes } \\
\text { No }\end{array}$ & $\begin{array}{l}320 \\
366\end{array}$ & $\begin{array}{l}46.65 \\
53.35\end{array}$ \\
\hline Hospitalization & $\begin{array}{l}\text { Yes } \\
\text { No }\end{array}$ & $\begin{array}{l}238 \\
448\end{array}$ & $\begin{array}{l}34.69 \\
65.31\end{array}$ \\
\hline Caries conditions (outcome & & $\mathbf{N}$ & $\%$ \\
\hline Prevalence of caries & $\begin{array}{l}\text { Yes (dmf-t } \geq 1) \\
\text { No (dmf-t00) }\end{array}$ & $\begin{array}{l}149 \\
537\end{array}$ & $\begin{array}{l}21.72 \\
78.28\end{array}$ \\
\hline
\end{tabular}


To identify the factors related to the presence or absence of dental caries, the associations between the dichotomous dependent variable (dmf-t $=0 /$ dmf-t $\geq 1$ ) and the outcome variables and covariates was determined; the data are presented in Table II. This preliminary evaluation verified that in addition to the outcome variables, the following covariates were crudely associated with the occurrence of dental caries: child's age, mother's level of education, family income, number of siblings, cariogenic diet and dental appointments.

Table II - Prevalence of caries and associated factors in children with sickle cell anemia in the state of Bahia

\begin{tabular}{|c|c|c|c|c|c|c|}
\hline \multirow{3}{*}{ Variable } & \multicolumn{4}{|c|}{ Prevalence of caries } & \multirow{3}{*}{\multicolumn{2}{|c|}{ p-value* }} \\
\hline & \multicolumn{2}{|c|}{ No $(\mathrm{dmf}-\mathrm{t}=0)$} & \multicolumn{2}{|c|}{ Yes $(d m f-t \geq 1)$} & & \\
\hline & \multicolumn{2}{|c|}{$n$} & \multicolumn{2}{|c|}{$\%$} & & \\
\hline \multicolumn{7}{|l|}{ Pain crisis } \\
\hline Yes & 58 & 38.98 & 91 & 61.07 & 0.0 & \\
\hline No & 308 & 57.36 & 229 & 42.64 & & \\
\hline \multicolumn{7}{|l|}{ Hospitalization } \\
\hline Yes & 72 & 48.32 & 77 & 51.68 & 0.0 & \\
\hline No & 376 & 70.02 & 161 & 29.98 & & \\
\hline \multicolumn{7}{|l|}{ Sex } \\
\hline Male & 267 & 77.17 & 79 & 22.83 & 0.4 & \\
\hline Female & 270 & 79.41 & 70 & 20.59 & & \\
\hline \multicolumn{7}{|l|}{ Age } \\
\hline 6 to 36 months & 390 & 90.91 & 39 & 9.09 & 0.0 & \\
\hline 37 to 96 months & 147 & 57.20 & 110 & 42.80 & & \\
\hline \multicolumn{7}{|l|}{ Skincolour } \\
\hline Black & 434 & 78.48 & 119 & 21.52 & 0.7 & \\
\hline Others & 103 & 77.44 & 30 & 22.56 & & \\
\hline \multicolumn{7}{|c|}{ Mother's level of education } \\
\hline 1 & 291 & 72.57 & 110 & 27.43 & 0.0 & \\
\hline 2 & 246 & 86.32 & 39 & 13.68 & & \\
\hline \multicolumn{7}{|l|}{ Family income } \\
\hline$<1 \mathrm{MS}$ & 381 & 75.15 & 126 & 24.85 & 0.0 & \\
\hline$\geq 1 \mathrm{MS}$ & 156 & 87.15 & 23 & 12.85 & & \\
\hline \multicolumn{7}{|l|}{ Number of siblings } \\
\hline 1 & 361 & 81.49 & 82 & 18.51 & 0.0 & \\
\hline$\geq 2$ & 176 & 72.43 & 67 & 27.57 & & \\
\hline \multicolumn{7}{|c|}{ Number of people in the household } \\
\hline$<4$ & 337 & 79.11 & 89 & 20.89 & 0.45 & 0.501 \\
\hline$\geq 5$ & 200 & 76.92 & 60 & 23.08 & & \\
\hline \multicolumn{7}{|l|}{ Number of rooms } \\
\hline$<5$ & 344 & 78.00 & 97 & 22.00 & 0.05 & 0.814 \\
\hline$\geq 6$ & 193 & 78.78 & 52 & 21.22 & & \\
\hline \multicolumn{7}{|l|}{ Sugar consumption } \\
\hline Yes & 282 & 71.21 & 114 & 28.79 & 27.52 & 0.000 \\
\hline № & 255 & 87.93 & 35 & 12.07 & & \\
\hline \multicolumn{7}{|l|}{ Dental appointment } \\
\hline Yes & 302 & 83.20 & 61 & 16.80 & 10.95 & 0.001 \\
\hline № & 235 & 7276 & 88 & 27.24 & & \\
\hline
\end{tabular}

After the multivariate analysis, it was observed that older children (aged from 37 to 96 months) with a cariogenic diet and without access to the dentist were more likely to present with caries, with statistically significant values. Mother's level of education of incomplete high school or more and a family income of greater than or equal to 1 minimum salary were considered protective factors.

For elaboration of the multiple Poisson regression model, the variables with the highest statistical significance ( $\mathrm{p} \leq 0.20$ ) were inserted into the two associations investigated (pain crisis and hospitalization/caries). The results related to the final model after the analysis showed that in the crude association, pain crisis is a factor associated with the occurrence of dental caries in children with sickle cell anemia (2.11-fold compared to the control). After adjustment, however, this association decreased to 1.24-fold and was not statistically significant. In relation to hospitalization, the results indicated a positive association, with the occurrence of dental caries in children with sickle cell anemia in the crude association (2.5-fold); however, after adjustment, the association decreased (1.46-fold) and did not show statistical significance, although it almost reached the level of significance (Table III).

Table III - Multivariate analysis of caries prevalence and associated factors in children with sickle cell anemia in the state of Bahia

\begin{tabular}{|c|c|c|c|c|}
\hline \multirow[b]{2}{*}{ Variable } & \multicolumn{4}{|c|}{ Prevalence of caries } \\
\hline & $\begin{array}{l}\text { OR crude } \\
\text { (CI 95\%) }\end{array}$ & p-value & $\begin{array}{l}\text { ORadjusted } \\
\text { (CI 95\%) }\end{array}$ & p-value ${ }^{\star}$ \\
\hline \multicolumn{5}{|l|}{ Hospitalization } \\
\hline Yes & $2.50(1.72-3.62)$ & 0.000 & $1.46(0.96-2.23)$ & 0.079 \\
\hline No & 1 & & 1 & \\
\hline \multicolumn{5}{|l|}{ Crisis of pain } \\
\hline Yes & $2.11(1.46-3.06)$ & 0.000 & $1.24(0.81-1.90)$ & 0.332 \\
\hline No & 1 & & 1 & \\
\hline \multicolumn{5}{|l|}{ Age } \\
\hline 6 to 36 months & 1 & 0.000 & & \\
\hline 37 to 96 months & $7.48(4.96-1.29)$ & & & \\
\hline \multicolumn{5}{|l|}{ Mother's level of education } \\
\hline Until elementary school & 1 & 0.000 & & \\
\hline Incomplete high school or more & $0.42(0.28-0.63)$ & & & \\
\hline \multicolumn{5}{|l|}{ Dentist appointment } \\
\hline Yes & 1 & 0.001 & & \\
\hline No & $1.85(1.28-0.68)$ & & & \\
\hline \multicolumn{5}{|l|}{ Family income } \\
\hline$<1 \mathrm{MS}$ & 1 & 0.001 & & \\
\hline$\geq 1 \mathrm{MS}$ & $0.45(0.28-0.72)$ & & & \\
\hline \multicolumn{5}{|l|}{ Sugar consumption } \\
\hline Yes & $2.95(1.95-4.46)$ & 0.000 & & \\
\hline № & 1 & & & \\
\hline
\end{tabular}

*Adjusted for age, mother's level of education, dentist appointment, family income and sugar consumption. 


\section{DISCUSSION}

As in the study by Laurence et al. [4], in which the severity of sickle cell disease was analysed by the number of episodes of vasoconstrictive crisis, in the present study, it was observed that the severity of sickle cell disease alone did not aggravate the prevalence of caries. In the same sense, Passos et al. [2] concluded that despite a greater number of caries in children with sickle cell anemia in relation to a control group, caries appear to be more associated with sociodemographic issues than with the severity of sickle cell disease. However, Fernandes et al. [3] found divergent results in their study. According to the authors, younger children with sickle cell anemia, aged between 8 and 10 years, had a lower prevalence of caries than the control group with healthy children, and there was no significant difference in quality of life of oral health reported between the groups. Furthermore, socioeconomic factors were not associated with the occurrence of caries, as opposed to the findings in relation to the severity of sickle cell disease. This divergence may have occurred due to differences in the risk factors for caries acquisition in the different localities.

The prevalence of caries found in the present study was low compared to the results found by Luna et al. [5] in their study of children with sickle cell anemia in the city of Recife, where a high prevalence of caries was found (55\% of children with cavities untreated). However, it should also be emphasized that the age group used was broader, involving children from 3 to 12 years of age, which may explain the difference. Fukuda et al. [6] also observed a reduced prevalence of decayed teeth when comparing 60 children with sickle cell anemia to subjects without the disease. Although the control group was restricted with regard to race and sex, the prolonged use of penicillin in this study was investigated as a confounding factor, which showed a significant reduction in the number of Streptococcus mutans in the oral cavity, thus justifying the results found. Among the interfering factors controlled for in this study, a previous history of the prolonged use of antibiotics was not recorded, which is therefore a limitation of this analysis that should be considered in other studies.

Compared with data from a national survey carried out in Brazil - SB Brazil 2003 [7] - in the age group of up to 36 months, the oral health status of the children in this study was better, with a ceo-d of 0.31 and a prevalence of caries of $9.09 \%$. Data from SB Brazil showed values of 1.1 and $27 \%$, respectively. In relation to the other studies that included the state of Bahia, the values found in this study had more positive results, except for the data obtained by Scavuzzi et al. [8], who reported a caries prevalence of 5.9\%. However, the age range of the children used by the previous authors was slightly lower (up to 30 months), which may explain this small difference in the occurrence of caries. In the present study, children with older than 36 had ceo-d of 1.86 , and $42.80 \%$ had at least one decayed tooth; these were similar values but still lower than those found in 5-year-old children in the SB Brazil project in 2003 [7] (2.8 and 59.37\%, respectively) and 2010 [9] (2.43 and $53.7 \%$, respectively). In general, the values found in the present study were lower than those of other studies; however, some authors [10-13] have found very similar values. This finding shows that there has been a change in the epidemiological profile of caries in recent years as well as a decline in the prevalence of caries, but there is no great difference between children who have and those who do not have sickle cell disease.

Regarding the data obtained on the severe clinical manifestations of the disease, $46.65 \%$ of the patients experienced pain attacks and $34.69 \%$ required hospitalization. In the studies conducted in children by Miller et al. [13] and Lanzkron et al. [14], values ranging from 24 to $54 \%$ of pain crises were found, similar results to those observed in the present study, but the latter found a percentage of $43.5 \%$ for hospitalization, a value slightly higher than that found in the present study.

Although the presence of caries and gingival alterations are not directly related to the systemic manifestations of sickle cell disease, they are influenced by the quality and condition of life, as is the case 
in systemically healthy patients [15]. As these systemic manifestations influence the quality of life of the patient with the disease, they also indirectly influence the presence of oral alterations, including caries. One of the characteristics of sickle cell anemia is its clinical variability: some patients have a very serious condition and are subject to numerous complications and frequent hospitalizations, whereas others present a more benign, in some cases almost asymptomatic, disease process. Both hereditary and acquired factors contribute to this clinical variability. Among the most important acquired factors is the socioeconomic level, with consequent variations in the quality of food, infection prevention and medical care [16].

Pain crises and hospitalization events were chosen for association in this study as factors related to the severity of the disease because patients with sickle cell disease usually have a history of multiple hospitalizations and painful crises, episodes of severe anemia, multiple blood transfusions and recurrent attacks of pulmonary bacterial infections [17]. These factors were also chosen based on the study by Laurence et al. [4], in which the clinical severity of sickle cell anemia was measured after asking how many hospitalization episodes had occurred. Loureiro and Rozenfeld [18] observed that the hospitalization rate is higher in the age group up to 9 years and decreases with advancing age. The age group analysed in the present study is similar to this younger age range, supporting the association of hospitalization with several factors, including dental caries.

A main limitation of the present study is its transversal design, as it does not allow cause-effect inferences between the mediating factors associated with dental caries. However, there are no conclusive studies in the literature relating the severity of the clinical manifestations of sickle cell anemia with the prevalence of caries in childhood, which may be considered an initial step and may serve as a basis for other studies. Additionally, the statistical analysis of the data used as an indicator of association, the odds ratio, was based on the Poisson regression. However, the possibility of overestimation of the data is highlighted because this is a cross-sectional study.

According to the methodology used in this study, certain demographic and socioeconomic characteristics that a population has or is exposed to can act as determinants in health conditions, since the age of the child, mother's degree of education, family income, diet and access to health services were factors associated with dental caries in the investigated group.

The results showed that the severity of the sickle cell condition alone was not sufficient to aggravate the prevalence of caries; therefore, there are no major differences between children with or without sickle cell disease. Although in the study population, the occurrence of pain and hospitalization due to sickle cell disease did not present a statistically significant association with caries after adjustment for the other variables, greater attention should be given to patients with sickle cell anemia because they are vulnerable to serious clinical manifestations of the disease, generating discomfort that may influence oral health conditions.

Knowledge of the association between dental caries and the severity of sickle cell anemia allows pediatric dentists to better understand the problem and its role in managing the health of these children.

\section{REFERENCES}

1. Pereira SA, Cardoso CS, Brener S, Proietti AB. Doença Falciforme e qualidade de vida: um estudo da percepção subjetiva dos pacientes da Fundação Hemominas, Minas Gerais, Brasil. Rev. Bras. Hematol. Hemoter., 2008;30(5):411-6.

2. Passos CP,Santos PR, Aguiar MC, Cangussu MC, Toralles MB, da Silva MC, et al. Sickle cell disease does not predispose to caries or periodontal disease. Spec Care Dentist. 2012;32:55-60.

3. Fernandes MLMF,Kawachil, Corrêa-FariaP,Pattusi MP,Paiva SM,Pordeus IA Caries prevalence and impact on oral health-related quality of life in children with sickle cell disease: cross-sectional study. BMC Oral Health. 2015;15:68.

4. Laurence B, George D, Woods D, Shosanya A, KatzRV, Lanzkron S, et al. The association between sickle cell disease and dental caries in African Americans. Spec Care Dentist. 2006;26:95-100.

5. Luna AC, Rodrigues MJ, Menezes VA, Marques KM, Santos FA. Caries prevalence and socioeconomic factors in children with sickle cell anemia. Braz Oral Res. 2012;26:43-9. 
6. Fukuda JT, Sonis AL, Platt OS, Kurth S. Acquisition of mutans Streptococciand caries prevalence in pediatric sickle cell anemia patients receiving long-term antibiotic therapy. Pediatr Dent. 2005;27:186-90.

7. $\quad$ BRASIL. Ministério da Saúde. SB Brasil 2002-2003: Pesquisa Nacional de Saúde Bucal: resultados principais. Braślia: Ministério da Saúde;2004.

8. Scavuzzi AIF, de Oliveira VG, FerreiraEA. Incremento de cárie dental em bebês residentes em feira de Santana/BA: acompanhamento de três anos. Pesqui Bras Odontopediatria Clín Integr. 2007;7:161-7

9. $\quad$ BRASIL. Ministério da Saúde. SB Brasil 2010:Pesquisa Nacional de Saúde Bucal: resultados principais. Brasília: Ministério da Saúde;2012.

10. Moura LdF, de Moura MS, de Toledo OA. Dental caries in children that participated in a dental program providing mother and child care.J Appl Oral Sci. 2006;14:53-60.

11. Lopes LS, Rossi TRA, Cangussu MCT. Ambiente familiar e cárie dentária em pré-escolares do município de Salvador (BA), 2005. Rev Baiana Saúde Pública. 2009;33:428.

12. Almeida TF,Cangussu MCT, Chaves SCL, Silva DIC, Santos SC. Condições de saúde bucal de crianças na faixa etária pré-escolar, residentes em áreas de abrangência do Programa Saúde da Família em Salvador. Bahia Brasil Rev Bras Saúde Mater Infant. 2009;9:247-52
13. Miller ST, Sleeper LA, Pegelow CH, Enos LE, Wang WC, Weiner SJ, etal. Prediction of adverse outcomes in children with sickle cell disease. N Engl $\mathrm{J}$ Med. 2000;342:83-9.

14. Lanzkron S, Carroll CP,Haywood C, Jr. The burden of emergency department use for sickle-cell disease: an analysis of the national emergency department sample database. Am J Hematol. 2010;85:797-9.

15. Soares FF, Rossi TRA, Brito MGS, Vianna MIP,Cangussu MCT.Condições de saúde bucal e fatores sociodemográficos de crianças de 6 a 96 meses com doença falciforme no Estado da Bahia. Rev Odontol UNESP, Araraquara. 2010;39:115-21.

16. BRASIL. Ministério da Saúde, Agência nacional de vigiância sanitária. Manual de diagnóstico e tratamento de doenças falciformes. Brasilia: ANVISA;2002.

17. Ramakrishna Y.Dental considerations in the management of children suffering from sickle cell disease: a case report. J Indian Soc Pedod Prev Dent. 2007;25:140-3.

18. Loureiro MM, Rozenfeld S. Epidemiology of sickle cell disease hospital admissions in Brazil. Rev Saude Publica. 2005;39:943-9.

\section{Anderson Santos Carvalho \\ (Corresponding address)}

Salvador-BA-Brasil Rua Bicuíba 573 ap 204 patamares

CP 41680050

Date submitted: 2019 Sep 24

E-mail: dedscarvalho@yahoo.com.br 